SHAKESPEARE: SEVEN TRAGEDIES 
Also by E. A. J. Honigmann

THE STABILITY OF SHAKESPEARE'S TEXT

SHAKESPEARIAN TRAGEDY AND THE MIXED RESPONSE

\author{
Also edited by E. A. J. Honigmann \\ KING JOHN \\ RICHARD III \\ TWELFTH NIGHT \\ PARADISE LOST, Book X (with C. A. Patrides) \\ MILTON'S SONNETS
}




\section{SHAKESPEARE: \\ SEVEN TRAGEDIES}

The dramatist's manipulation of response

E. A. J. HONIGMANN

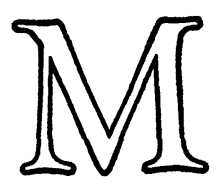


ISBN 978-1-349-02931-o (eBook) DOI 10.1007/978-1-349-02931-o

(C) E. A. J. Honigmann 1976

Softcover reprint of the hardcover 1st edition 1976 978-o-333-19598-7

All rights reserved. No part of this publication may be reproduced or transmitted, in any form or by any means, without permission

First published 1976 by THE MACMILLAN PRESS LTD London and Basingstoke Associated companies in New York Dublin Melbourne Johannesburg and Madras

SBN 333195981

This book is sold subject to the standard conditions of the Net Book Agreement 


\section{Contents}

Acknowledgements vi

A Note on Dates and Definitions vii

1 Introduction: Shakespeare and the Study of Response 1

2 Impressions of 'Character' 4

3 Response and Dramatic Perspective 16

4 Sympathy for Brutus 30

5 Hamlet as Observer and Consciousness 54

6 Secret Motives in Othello 77

7 Lear's Mind 101

8 Macbeth: the Murderer as Victim 126

9 Antony versus Cleopatra 150

10 The Clarity of Coriolanus 170

$\begin{array}{lr}\text { Conclusion } & 192\end{array}$

$\begin{array}{ll}\text { Notes } & 194\end{array}$

Index of Names $\quad 211$

Index of Technical Terms $\quad 214$ 


\section{Acknowledgements}

I am grateful to the University of Newcastle upon Tyne for permission to reprint short passages from my lecture, Shakespearian Tragedy and the Mixed Response (Newcastle upon Tyne, 1971); and to Miss Kathleen O'Rawe, who managed to decipher my 'foul papers' and produced the typescript. I am also most grateful to an old friend, R. A. Foakes, who read through the typescript and suggested several corrections and improvements. 


\section{A Note on Dates and Definitions}

In his first ten years or so as a dramatist Shakespeare wrote a few tragedies (notably Romeo and Juliet) but specialised in comedy and the history-play. In his second decade he was pre-eminently a writer of tragedy, and composed the mature tragedies in the following order: Julius Caesar (1599), Hamlet (1600-1), Othello (1603), King Lear (1605), Macbeth (1606), Antony and Cleopatra (1606-7) and Coriolanus $(1607-8)$. The order is now pretty well agreed, but the dates are not so certain. ${ }^{1}$ Yet at much the same time, it should be remembered, he also produced other plays, most of them comedies: As You Like It (1599-1600), Twelfth Night (1599-1600), The Merry Wives of Windsor (1600-1), Troilus and Cressida (1601-2), All's Well That Ends Well (1602-3), Measure for Measure (1603-4) and Timon of Athens (1607-8). The dates, again, have to be regarded as conjectural.

The mature tragedies are traditionally divided into two groups, the 'Roman plays' (Julius Caesar, Antony and Cleopatra, Coriolanus), and the four to which I sometimes refer as 'the central tragedies' (Hamlet, Othello, King Lear, Macbeth). Each group has its distinctive features. ${ }^{2}$ The Roman plays, all based on the same source - Plutarch's Lives in Sir Thomas North's translation (1579) - express Roman attitudes to the state, to religion, suicide, love and marriage, whereas the central tragedies are more 'Elizabethan' and Christian in outlook. The Roman plays examine political questions, the central tragedies have a more metaphysical bent. But these are rough and ready distinctions, for King Lear is less overtly Christian than the three other central tragedies, the Roman plays all include some Elizabethan (or Jacobean) elements, and the tragedies might be grouped quite differently. We might distinguish, for example, between those that exhibit supernatural phenomena (Julius Caesar, Hamlet, Macbeth and, perhaps, Antony and Cleopatra) and the rest, or between tragedies of thought (Julius Caesar, Hamlet) and the rest. I deal with the seven mature tragedies individually, in chronological order, without paying much attention to groups, and so I must stress that the two traditional groups also differ in their manipulation of 
audience-response. In the Roman plays the audience enters less completely into the hero's point of view than in the central tragedies, which no doubt contributes to our sense that we are here concerned with a different kind of play. Brutus, Antony and Coriolanus reveal less of their 'inner self' or have less to reveal, fall short of the four 'central' heroes in spiritual grandeur, and are less generously endowed with Shakespeare's finest poetry. For these and other reasons the spectator identifies himself less fully with the Roman heroes, and, I think, admires them less. In addition spectators are 'disengaged' from the Roman heroes, particularly Antony and Coriolanus, by the unusual number of comment-speeches; they know how the Roman heroes appear to others from the outside, but, paradoxically, this knowledge conceals the inner man and helps to keep him at a distance.

There is no discussion of Timon of Athens in this book. As I have explained elsewhere, ${ }^{3}$ Timon differs profoundly from the tragedies of the same period and has more in common with Troilus and Cressida, another play whose genre is hard to define. If Timon was regarded by Shakespeare as properly finished and was ever performed in his lifetime, it must have aroused a unique response. Some scenes appear to steer towards tragic emotions, but very few can be said to be tragic, since alien emotions almost always intrude: Timon's rage cannot compare with Lear's, affecting us as spiteful and grotesque, even petty, where Lear's is, quite simply, sublime. The audience, I think, would have been so 'disengaged' from Timon that it might well have wondered, in many scenes, whether it was watching a tragedy or a freak-show.

There is an index of technical and unfamiliar terms on page 214.

All quotations from Shakespeare are taken from Peter Alexander's edition of The Complete Works (Tudor edition, 1951), unless otherwise specified. 